\begin{tabular}{c} 
Volume and Issues Obtainable at Center for Sustainability Research and Consultancy \\
Journal of Accounting and Finance in Emerging Economies \\
ISSN: 2519-0318 ISSN (E) 2518-8488 \\
Volume 5: Issue 1 June 2019 \\
JSRᄃ \\
Journal homepage: $\underline{\text { www.publishing.globalcsrc.org/jafee }}$ \\
\hline
\end{tabular}

\title{
Web Disclosure as Mediating Role in the Relationship Between Paradox of Choice, Investor Experience, Financial Literacy and Investment Decision Making: Evidence From China
}

\author{
${ }^{1}$ Noheed Khan, ${ }^{2}$ Khalid Latif, ${ }^{3}$ Nadeem Sohail, ${ }^{4}$ Zohaib Zahid \\ ${ }^{1}$ Assistant Professor, College of Commerce, Government College University Faisalabad.Pakistan, \\ Email: noheedkhan@gcuf.edu.pk \\ ${ }^{2}$ Assistant Professor, College of Commerce, Government College University Faisalabad.Pakistan, Email: \\ Khalidlatif@gcuf.edu.pk \\ ${ }^{3}$ Assosiate Professor, College of Commerce, Government College University, Faisalabad. Pakistan \\ ${ }^{4} \mathrm{PhD}$ (Finance) Scholar, School of finance, Southwestern University of Finance and Economics China
}

\begin{tabular}{ll}
\hline \multicolumn{1}{c}{ ARTICLE DETAILS } & ABSTRACT \\
\hline History & Purpose: The aims of this study to find the web disclosure as mediating \\
Revised format: May 2019 & role in the relationship between paradox of choice, investor experience, \\
Available Online: June 2019 & financial literacy and investment decision making.. \\
& Design/Methodology/Approach: Data were obtained from the 200 \\
& respondents for recent empirical investigation. The structural equation \\
Keywords & model is employed for analyzing the data. \\
Web Disclosure, Paradox, & Findings: The novel findings suggest that paradox of choice, investor \\
Financial Literacy, Investment & experience, and financial literacy have direct positive effect on investment \\
Decision & decision making. Moreover, the findings recommend that web disclosure \\
& acts as a mediator between paradox of choice, investor experience, \\
JEL Classification: & financial literacy and investment decision making \\
Implications/Originality/Value: The novel findings recommend that an & important policy implication of web information disclosure for the \\
& investor.
\end{tabular}

(C) 2019 The authors, under a Creative Commons Attribution-Non

Commercial 4.0

Corresponding author's email address: noheedkhan @gcuf.edu.pk

Recommended citation: Khan, N., Latif, K., Sohail, N. and Zahid, Z. (2019). Web Disclosure as Mediating Role in the Relationship Between Paradox of Choice, Investor Experience, Financial Literacy and Investment Decision Making: Evidence From China. Journal of Accounting and Finance in Emerging Economies, 5 (1), 83-92

DOI: $10.26710 /$ jafee.v5i1.719

\section{Introduction}

Investment decision behavior has been incorporated into human psychology. Human psychology triggers well when there is a number of financial investment opportunities are available. Therefore, financial opportunities may involve but not limited to buying and selling of financial products with a vital purpose to make a profit (Diliberto, 2006; Mudholkar, 2007; Pompian, 2008). The primary objective of the investment decision making is to gain optimal income by minimized opportunity loss. Nevertheless, the probability of loss increase when the investor has many options to invest (Jabbarova, 2016). So, the investment decision is a problem when the market is not fully disclosed and asymmetric and investor tries to use many disclosed information to avoid this situation. 
Asymmetric information prevails in the financial market which effects the investor behavior (Chandra \& Kumar, 2011). Along with, numerous financial product and complicities in the financial market which increased complication for an investor in clicking the right decision (Lovric, Kayman, \& Spronk, 2008; Sjöberg \& Engelberg, 2006). In this regard, Web disclosure helps the investor for selecting the optimal choice (Cormier, Aerts, LEDOUX, \& Magnan, 2010) and it also affects the earning depend on nature of disclosed information (Cormier, Ledoux, \& Magnan, 2009). Financial crisis can be tackled if the firm discloses the proper risky information on time (Jorion, 2002). Furthermore, disclosed information creates a helping bridge for an investor to understand relationship gap between market information and financial statement (Aerts, Cormier, \& Magnan, 2007; Amir \& Lev, 1996; Lev \& Zarowin, 1999).

The objective of this study to explore the mediation effect on the relationship between paradox of choices, investor experience, financial literacy and investment decision making. This study will create novelty in different ways: first, prior researchers have been studied the human psychology with investment decision making perspectives (Charles \& Kasilingam, 2013 investor has a wide array of investment opportunity (Mottola \& Utkus, 2003), called the paradox of choices. Although investor has many options he selects only a few preferable options, the paradox of choice recommends that always, it could not be true. Additionally, many options provide the investor to make a better decision. While extensive options may overload the investor choice validate to be demotivated and leading to "decision paralysis" (Iyengar \& Lepper, 2000). Particularly, psychological literature regarding the paradox of choice phenomenon base on decision-making behavior. If an investor has experience and financial knowledge then he can select a better choice. Many preferences may be less when experienced and financial knowledgeable investor performs a task (Connolly \& Ordóñez, 2003; J. F. Smith \& Kida, 1991).

Second, Web disclosure helps in the paradox of choice phenomenon to make the investment decision. Investor experience and financial knowledge help the investor to understand web disclosure and also investment decision making (Slovic, Finucane, Peters, \& MacGregor, 2002). Third, The Chinese economy has become the second largest economy in the world (Barboza, 2010). By the continuous growth, it was started the development of their capital markets in 1990 while it became the world second largest market in 2014 (Carpenter \& Whitelaw, 2017).

The findings of the study validate the direct relationship of the paradox of choice, investor experience, and financial literacy with investment decision making. The imperial findings have also confirmed that web disclosure act as a mediator on the relationship between the paradox of choice, investment experience, financial literacy and investment decision making. The recent study contributes to present literature on numerous aspects. First, according to our best knowledge, none of the study used before web disclosure as a mediator on the relationship between the paradox of choice and investment decision making. Second, this study extends the behavioral finance literature by using the paradox of choices in the Chinese context. Third, this study also contributes to the heuristic investor decision-making theory.

\section{Literature review}

Investment decision includes the commitment of outflow in the form of capital to obtain cash inflow and benefits in the future (Adair, Berry, \& McGreal, 1994). In the past, many research scholars have been attracted in decision making due to its complexities and future results (March, 1994). Decision making is considered as an integral part of the managerial level and organization research (Chia, 1994; Yu \& Chen, 2010) and optimal allocation of resources among available opportunity is a major part of investment decision making. Therefore, investment decision making based on serval key elements like the paradox of choice, financial literacy, investor experience and disclosed information, etc. The idea paradox has been become considered by management and organization research committee (Bloodgood \& Chae, 2010; Fredberg, 2014; W. K. Smith \& Lewis, 2011). The paradox of choice helps the investor to get a deep understanding of investment opportunities. The paradox of choice is a game theory (Moore, 1994) it might be possible that selected opportunity will not a grantee of optimal choose in future but it still best opportunity among available options (Simon, 1965).

The paradox of choice phenomenon plays a significant role in investment decision making and prior studies have been discussed in different perspectives. Iyengar and Lepper (2000) discussed that in the presence of more options investors lose their decision-making ability. Moreover, Sethi-Iyengar, Huberman, and Jiang (2004) suggest that many options adversely effect on preferences. Kempf and Ruenzi (2006) argued that when an investor has more options then he becomes the status quo. Prior research findings suggest that more option adversely effect on the preferences and also increase the probability of the delay decision making (Chernev, 2003). 
In this regard, Investor experience is a key element to access the optimal preference to get the desired result in the future (Schwartz, 2004a, 2004b, 2005). Investor experience and financial knowledge support to understand and select investment alternatives (Chernev, 2003). Prior studies have explained that investment decision making may be affected if the investor has no practical investment experience. Sethi-Iyengar et al. (2004) the study recommends that individual experience help to select the preferences. The error occurs in available opportunity due to the reasoning process (Edwards, 1983). Phillips and Edwards (1966) suggests that human can perform better with a familiar task. J. F. Smith and Kida (1991) stated that when professionals perform the same task they perform better than a new task.

Although investor experience assists the investor in the investment decision-making process however, the investor cannot understand the financial terminology without financial knowledge. Financial knowledge is necessary because of the increase in new financial product and economic condition. So, financial literacy increases understanding of the available options along with it also decrease the investment options by limiting the optimal opportunity (Kida, Moreno, \& Smith, 2010; Lusardi \& Mitchell, 2007a, 2007b). The investor can get a good rate of return on investment with financial literacy and incentive to increase financial literacy mean an increase in financial knowledge and saving (Jappelli \& Padula, 2013).

Financial literacy impacts financial decision-making and makes it more affected (Howlett, Kees, \& Kemp, 2008). An investor with less financial knowledge is less likely to invest in a financial market like the stock market and financial knowledge is a positive impact on investment behavior (Mouna \& Anis, 2017). Hathaway and Khatiwada (2008) argued that financial literacy improved the investment decision making and affects the investor behavior as a result investor can get more cash inflow in the future by investing in optimal assets (Abreu \& Mendes, 2010). Chen and Volpe (1998) suggests that investor with a high level of financial knowledge perform a better saving and investment decision. Along with, financial literacy pushes the investor to enter into complex commodity market to get the benefit (Hsiao \& Tsai, 2018). The study of Hassan Al-Tamimi and Anood Bin Kalli (2009) states that financial literacy has a direct positive relationship with investment decision process (Aren \& Zengin, 2016). Moreover, if investor financial literacy is high then he preferred to invest in equity market less likely go for deposit. Although, the paradox of choice, Investor experience and financial literacy important elements for investment decision making but their fundamental role can be enhanced by available web disclosed transparent information (Lee \& Joseph, 2013). Valentinetti, Rea, and Basile (2016) suggests that several factors of financial disclosure because if the investor has web disclosed information with above mention skills then the investor can make a quick decision by understanding the financial terminology and experience (Hillenbrand \& Schmelzer, 2017). Prior studies suggest that firms who preferred web disclosure, they enjoyed the greater benefit and this information is also helpful for an investor in decision making (Gandia, 2011; Saxton \& Guo, 2011; Saxton, Kuo, \& Ho, 2012).

Web information is disclosed in three types categorical, semantic and feature information (Hartmann, Ma, \& Vechsamutvaree, 2016; Wong et al., 2017). Cardoso, Leite, and de Aquino (2016) argued that web disclosure is the best way to disclose the information. It provides direct information, there is no need for intermediaries to collect the information (Lymer, 1999). Web disclosure is a versatile way of communication between manager and investor. Information on the web consists of the investor and financial statement related information (Ashbaugh, Johnstone, \& Warfield, 1999; Debreceny, Gray, \& Rahman, 2002).

The goal of this study is to bring in a discussion about the paradox of choice, investor experience, and Heuristic theory suggests that how individual investor behavior affects the investment decision-making process (Lucey \& Dowling, 2005). We proposed a hypothesis in the light of the above discussion investor financial literacy affect the investment decision making as a mediating role of web disclosure. The and heuristic theory.

H1 (a) - Paradox of Choice has a positive effect on the investment decision-making process.

H1 (b) - Investor experience has a positive effect on the investment decision-making process.

H1 (c) - Investor financial literacy has a positive effect on the investment decision-making process.

H2 (a): Web disclosure has a mediating effect on the relationship between the paradox of choice and investment decision-making process.

H2 (b): Web disclosure has a mediating effect on the relationship between investor experience and investment decision-making process. 
H2 (c): Web disclosure has a mediating effect on the relationship between investor financial literacy and investment decision-making process.

\section{Research Methodology}

Data were collected from three various methods, telephone, personal and email from October to December 2017. The respondents for the recent study were randomly selected from Beijing while they have an investment in Chinese security companies. The questionnaire was prepared in dual languages, English and Chinese. We followed (Baloch, Meng, Xu, Cepeda-Carrion, \& Bari, 2017; Cohen \& Diamant, 2017) study for translation and discussion. We hired the four bilingual experts of which three were a bilingual financial expert and one was the professional translator. We discussed the survey instrument with two bilingual financial experts. They translated the questionnaire from the original language to the Chinese language. Further, transferred the questionnaire to the third expert. The survey instrument was reviewed by the third expert. The discrepancies were found and forwarded to a language expert. All the discrepancies were removed and approved the survey instrument. Further, the 300 respondents were targeted for this study while 200 respondents gave the response. The response rate was $67 \%$. The partial least square method is used for data analysis. It is based on structure equational model (Henseler, 2017). This study prefers PLS over the regression models due to the following causes. First, it provides a more robust result and has fewer identifications issues and it also provides better results in a complex problem. Second, a recent study sample is small (Henseler, 2017). Third, PLS has an appropriate measure when the model has an indicator (< 6) and study sample (>100) (Hair, Hult, Ringle, Sarstedt, \& Thiele, 2017). The recent study contains the less than six indicators and sample size contain the two hundred respondents.

\section{Results}

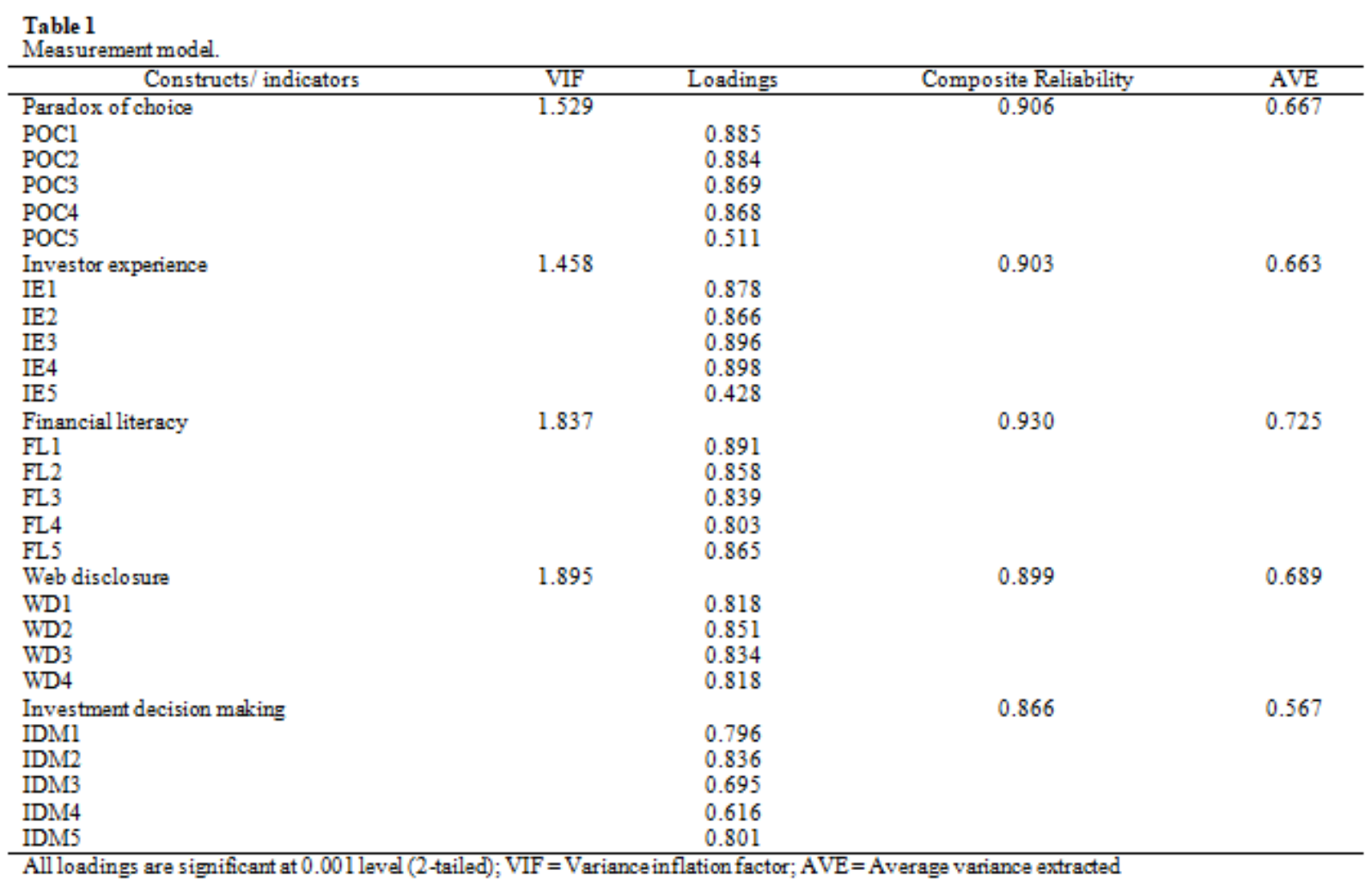

Table1 shows that the items having the loading value greater than 0.7 fulfill the requirements of the reliability test. Some items having the loading value close to 0.7 , therefore the researcher has to take a decision to include or exclude them for the scale's content validity. Furthermore, all dimensions and constructs pass the criterion of construct validity as their composite reliabilities (CR) are above the threshold value of 0.7 . Moreover, table 1 shows that the constructs and dimensions having an average variance extracted (AVE) value greater than 0.5 level or near to 0.5 level pass the convergent validity test.

Table 2 depicts the discriminant validity test results which show that all the constructs passes the discriminant validity test as their HTMT90 and Fornell-Larcker values are within range. All the variables are having HTMT 
value less than 0.85 and their Fornell-Larcker criteria show that the square root of AVE value of each construct is higher than the other constructs' correlation values. These results confirmed that the model passes the discriminant validity (Henseler, Ringle, \& Sarstedt, 2015).

\section{Table 2}

Measurement model. Discriminant validity.

\begin{tabular}{|c|c|c|c|c|c|c|c|c|c|c|}
\hline \multicolumn{6}{|c|}{ Fornell-Larcker Criterion } & \multicolumn{5}{|c|}{ Heterotrait-monotrait ratio (HTMT) } \\
\hline & FL & IDM & IE & POC & WD & FL & IDM & IE & POC & WD \\
\hline$\overline{\mathrm{FL}}$ & 0.852 & & & & & & & & & \\
\hline IDM & $0.581 * * *$ & 0.753 & & & & 0.644 & & & & \\
\hline IE & $0.479 * * *$ & $0.484 * * *$ & 0.814 & & & 0.542 & 0.575 & & & \\
\hline POC & $0.518 * * *$ & $0.432 * * *$ & $0.410 * * *$ & 0.817 & & 0.572 & 0.505 & 0.484 & & \\
\hline WD & $0.616 * * *$ & $0.495 * * *$ & $0.505^{* * *}$ & $0.520 * * *$ & 0.830 & 0.697 & 0.567 & 0.583 & 0.575 & \\
\hline
\end{tabular}

Notes: FL = Financial Literacy; IDM = Investment decision making; IE = Investor experience; POC = Paradox of choice; WD = Web disclosure; $* * * p<0.01$

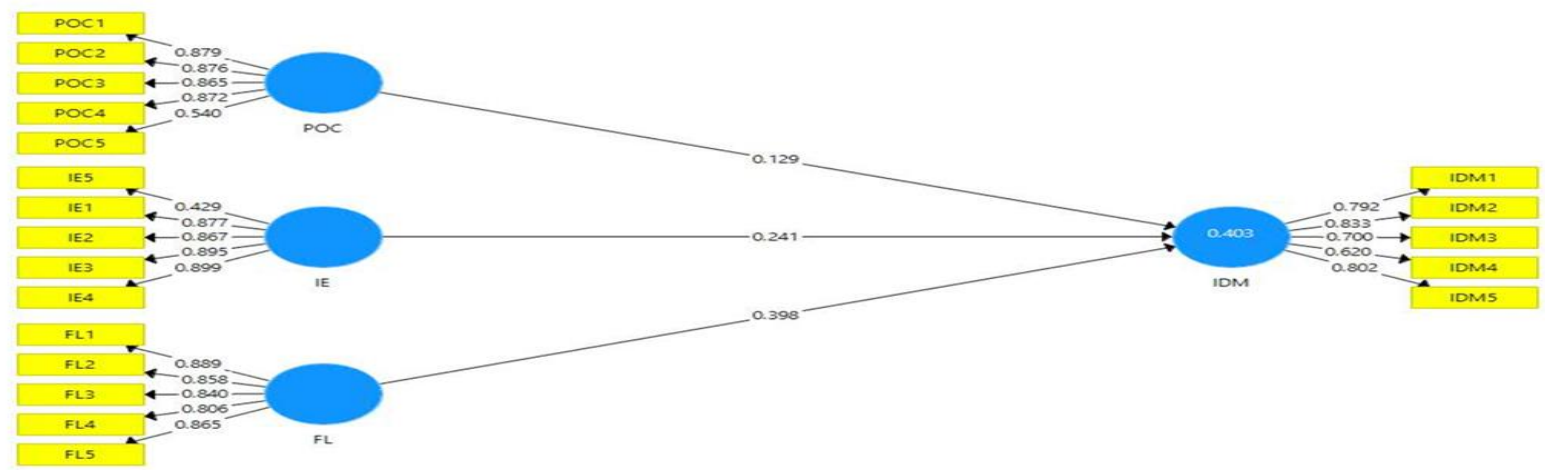

\section{Figure 1}

\subsection{The Structural model}

The structural assessment of the two models is shown in figure 2 and the main parameters of the structural assessment are given in table 3. It is evident from the values of the total effect coefficients c1 (POC), c2 (IE) and c3 (FL) that there are a significant total effect of these variables (POC, IE, and FL) on IDM (see Model 1).

Whereas the direct effects $\mathrm{c1}^{\prime}$ (POC), $\mathrm{c}^{\prime}$ ' (IE) and c3' (FL) on IDM are significant but shows a decreasing trend when WD is introduced in the analysis. Moreover, the regression coefficients $\mathrm{a} 1, \mathrm{a} 2, \mathrm{a} 3$, and $\mathrm{b}$ are significant. Therefore, the decreasing trend of direct effects $\mathrm{c}^{\prime}$ (POC), c2 ' (IE) and c3' (FL) and significant values of regression coefficients (a1, a2, a3 and b) leads to the conclusion that WD acts as a mediator between POC and IDM; IE and IDM; FL and IDM. Therefore, the hypothesis of this study H2-a, H2-b and H2-c are accepted and web disclosure (WD) role as a mediator is established in this study. However, the significance of $(\mathrm{a} 1 \times \mathrm{b})(\mathrm{a} 2 \times \mathrm{b})(\mathrm{a} 3 \times$ b) significance is yet to be tested for mediation (Hayes, 2009).To test the above-mentioned condition, SmartPLS is used for obtaining the indirect effects which turned out to be significant (Table 4). These results support the H2-a, $\mathrm{H} 2-\mathrm{b}$ and H2-c hypotheses. Thus, the study established partial mediation of WD between POC and IDM, IE and IDM, FL and IDM due to the facts that both the direct coefficients (c1, c2 and c3) and indirect coefficients $((\mathrm{a} 1 \times \mathrm{b})$ $(\mathrm{a} 2 \times \mathrm{b})$ and $(\mathrm{a} 3 \times \mathrm{b})$ are significant (Baron \& Kenny, 1986). Furthermore, to support the results more, this study calculates the standardized root mean square (SRMR). The SRMR discrepancy between the model implied correlations and the observed correlations for the two models (direct effect model and indirect effect model) as mentioned in (DeFond, Wong, \& Li, 1999) Following the footsteps of (DeFond et al., 1999), present study calculates the SRMR of composite factor model. As the SRMR (Model 1) turned out to be 0.054 for the composite factor model, which is well below the threshold value of 0.07 so the appropriate fit is assumed (DeFond et al., 1999). Whereas, the SRMR (Model 2) is turned out to be 0.07 for the composite factor model which is still better. 
These results lead to the conclusion that web disclosure acts as a mediator between POC and IDM, IE and IDM, FL and IDM.

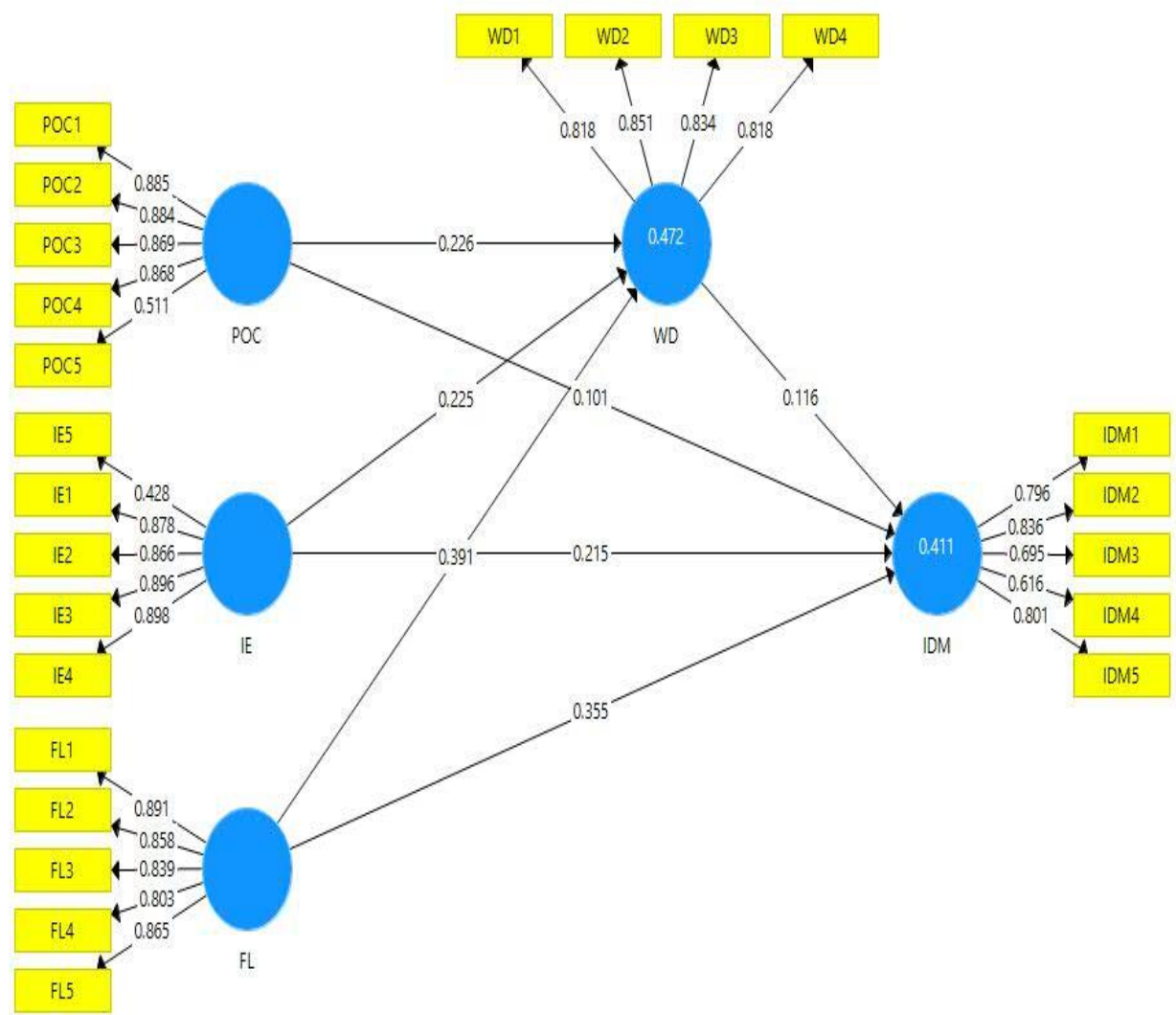

\section{Figure 2}

Table 3

Significant testing results of the structural model path coefficients.

\begin{tabular}{|c|c|c|c|}
\hline \multirow[t]{3}{*}{ Relationships } & Model 1 & Model 2 & \multirow[t]{3}{*}{ Support } \\
\hline & & $\mathrm{R}^{2} \mathrm{wD}=0.59 / \mathrm{Q}^{2} \mathrm{wD}=0.38$ & \\
\hline & $\mathrm{R}^{2} \mathrm{DM}=0.403 / \mathrm{Q}^{2}=0.210$ & $\mathrm{R}^{2} \mathrm{IDM}=0.411 / \mathrm{Q}^{2} \mathrm{IDM}=0.46$ & \\
\hline $\mathrm{H} 1-\mathrm{a} \mathrm{POC} \rightarrow \mathrm{IDM}$ & $\left(c_{1}\right) 0.129^{* 4 *}(6.071)$ & $\left(c_{1}\right) 0.116^{* *}(1.809)$ & Yes \\
\hline $\mathrm{H} 1-\mathrm{b}: \mathrm{IE} \rightarrow \mathrm{IDM}$ & $\left(c_{2}\right) 0.241^{* * *}(4.416)$ & $\left(c_{2}\right) 0.215^{* * *}(3.853)$ & Yes \\
\hline H1-c: FL $\rightarrow$ IDM & $\left(c_{3}\right) 0.398^{* * *}(6.071)$ & $\left(c_{3}\right) 0.355^{* * *}(5.032)$ & Yes \\
\hline $\mathrm{POC} \rightarrow \mathrm{WD}=\mathrm{a}_{1}$ & & $0.226^{* * *}(4.533)$ & \\
\hline $\mathrm{IE} \rightarrow \mathrm{WD}=\mathrm{a}_{2}$ & & $0.225^{4 * 4}(5.207)$ & \\
\hline $\mathrm{FL} \rightarrow \mathrm{WD}=\mathrm{a}_{3}$ & & $0.391^{* * *}(6.023)$ & \\
\hline $\mathrm{WD} \rightarrow \mathrm{IDM}=\mathrm{b}$ & & $0.116^{* *}(1.809)$ & \\
\hline
\end{tabular}

Table 4 


\begin{tabular}{|c|c|c|c|c|c|c|c|c|c|c|c|c|c|c|}
\hline & \multicolumn{4}{|c|}{ Total effect on IDM (Model 1) } & \multicolumn{5}{|c|}{ Direct effects on IDM (Model 2) } & \multicolumn{5}{|c|}{ Indirect effects on IDM (Model 2) } \\
\hline & \multirow[b]{2}{*}{ Path } & \multirow[b]{2}{*}{$\mathbf{t}$} & \multicolumn{2}{|l|}{ BCCI } & \multirow{2}{*}{\multicolumn{2}{|c|}{ Path }} & \multirow[b]{2}{*}{$\mathbf{t}$} & \multicolumn{2}{|l|}{ BCCI } & \multirow{2}{*}{\multicolumn{2}{|c|}{$\begin{array}{c}\text { Point } \\
\text { estimate }\end{array}$}} & \multicolumn{2}{|c|}{$\mathrm{BCCI}$} & \multirow[b]{2}{*}{$\mathrm{Sig}$} \\
\hline & & & Lower & Upper & & & & Lower & Upper & & & Lower & Upper & \\
\hline $\begin{array}{l}\text { POC } \\
\text { (cl) }\end{array}$ & $0.129 * * *$ & 6.071 & 0.260 & 0.519 & $\begin{array}{l}\mathrm{Hl}- \\
\mathrm{a}= \\
\mathrm{c}^{\prime} \mathbf{l}\end{array}$ & $0.116^{* *}$ & 1.809 & 0.10 & 0.35 & $\begin{array}{c}\mathrm{H} 2-\mathrm{a}=\mathrm{albl} \\
\text { (via WD) }\end{array}$ & 0.026 ** & 0.001 & 0.065 & Yes \\
\hline IE (c2) & $0.241^{* * *}$ & 4.416 & 0.136 & 0.347 & $\begin{array}{l}\mathrm{Hl}- \\
\mathrm{b}= \\
\mathrm{c}^{\prime} 2\end{array}$ & $0.215^{\star \star \star}$ & 3.853 & 0.17 & 0.40 & $\begin{array}{c}\mathrm{H} 2-\mathrm{b}=\mathrm{a} 2 \mathrm{bl} \\
\text { (via WD) }\end{array}$ & 0.026 ** & 0.002 & 0.057 & Yes \\
\hline FL (c3) & $0.398 * * *$ & 6.071 & 0.022 & 0.238 & $\begin{array}{l}\mathrm{Hl}- \\
\mathrm{c}= \\
\mathrm{c}^{\prime} 3\end{array}$ & $0.355^{* \star *}$ & 5.032 & 0.07 & 0.31 & $\begin{array}{c}\text { H2-c }=\text { a3bl } \\
\text { (via WD) }\end{array}$ & $0.045^{* *}$ & 0.003 & 0.108 & Yes \\
\hline $\begin{array}{l}\text { Notes: } \\
\text { decision }\end{array}$ & $\begin{array}{l}\text { CCI: Bias } \\
\text { making; IF }\end{array}$ & $\begin{array}{l}\text { Invected } \\
\text { Investo }\end{array}$ & $\begin{array}{l}\text { confide } \\
\text { r experi }\end{array}$ & $\begin{array}{l}\text { nce inter } \\
\text { ence; PO }\end{array}$ & $\begin{array}{l}\text { 1. Boc } \\
=\text { Par }\end{array}$ & $\begin{array}{l}\text { tstrapping } \\
\text { adox of cho }\end{array}$ & $\begin{array}{l}\text { ased or } \\
\text { e; WD }\end{array}$ & $\begin{array}{l}\mathrm{n}=5000 \\
=\mathrm{Web} \mathrm{d}\end{array}$ & $\begin{array}{l}\text { subsamp } \\
\text { sclosure }\end{array}$ & s. FL = Finan & cial Litera & cy; IDM & $=$ Invest & ment \\
\hline
\end{tabular}

\section{Discussion and conclusion}

The recent study finds the relationship between the paradox of choice, investor experience, and financial literacy and investment decision making by examining the web disclosure as a mediating role. Numerous studies have been used in different variables with investment decision making. Nevertheless, investment decision-making problem remains unsolved whether web disclosure has more indirect effect brought through the paradox of choice, investor experience, and financial literacy.

First, the recent study findings reveal that paradox of choice, investor experience, and financial literacy have a significant positive relationship with investment decision making. Second, web disclosure act as a mediating role in the relationship between paradoxes of choice, investor experience and financial literacy with investment decision making. Our direct relationship findings are in line with (Abreu \& Mendes, 2010; Chernev, 2003; Kida et al., 2010). Our web disclosure findings are also consistent with Cormier et al. (2010) and Cormier et al. (2009), they reported that Web disclosure helps the investor for selecting the optimal choice and it also affects the earning depend on nature of disclosed information. These findings lead to the conclusion that web disclosure helps the investor to decide to invest through the paradox of choice, investor experience, and financial literacy.

The recent study contributes to present literature on numerous aspects. First, according to our best knowledge, none of the study used before web disclosure as a mediator on the relationship between the paradox of choice and investment decision making. Second, this study extends the behavioral finance literature by using the paradox of choices in the Chinese context. Third, this study also contributes to the heuristic investor decision-making theory for web disclosure context. The findings of the study would be supportive of an investor, capital market policy maker.

The novel findings suggest that the Chinese policymaker make those policies which enforce the business firms, institutions and government bodies to disclose periodic information on web timely and frequently. The recent study has a few limitations. First, this study focuses on security company investor and ignore the other investor which have an investment in banks and financial institutions. Second, this study uses web disclosure as a mediator and ignore the types of web disclosure. The recent study opens the broad avenue for future researchers of the following ways. First, the researcher would check this novel model in the international setting. Second, the researcher would be added some other variable which makes more efficient decision to invest. 


\section{References}

Abreu, M., \& Mendes, V. (2010). Financial literacy and portfolio diversification. Quantitative finance, 10(5), 515528.

Adair, A., Berry, J., \& McGreal, W. (1994). Investment decision making: a behavioural perspective. Journal of Property Finance, 5(4), 32-32.

Aerts, W., Cormier, D., \& Magnan, M. (2007). The association between web-based corporate performance disclosure and financial analyst behaviour under different governance regimes. Corporate Governance: An International Review, 15(6), 1301-1329.

Amir, E., \& Lev, B. (1996). Value-relevance of nonfinancial information: The wireless communications industry. Journal of accounting and economics, 22(1-3), 3-30.

Aren, S., \& Zengin, A. N. (2016). Influence of financial literacy and risk perception on choice of investment. Procedia-Social and Behavioral Sciences, 235, 656-663.

Ashbaugh, H., Johnstone, K. M., \& Warfield, T. D. (1999). Corporate reporting on the Internet. Accounting horizons, 13(3), 241-257.

Baloch, M. A., Meng, F., Xu, Z., Cepeda-Carrion, I., \& Bari, M. W. (2017). Dark Triad, Perceptions of Organizational Politics and Counterproductive Work Behaviors: The Moderating Effect of Political Skills. Frontiers in psychology, 8, 1972.

Barboza, D. (2010). China passes Japan as second-largest economy. The New York Times, 15.

Baron, R. M., \& Kenny, D. A. (1986). The moderator-mediator variable distinction in social psychological research: Conceptual, strategic, and statistical considerations. Journal of personality and social psychology, 51(6), 1173.

Bloodgood, J. M., \& Chae, B. (2010). Organizational paradoxes: Dynamic shifting and integrative management. Management Decision, 48(1), 85-104.

Cardoso, R. L., Leite, R. O., \& de Aquino, A. C. B. (2016). A Graph is Worth a Thousand Words: How Overconfidence and Graphical Disclosure of Numerical Information Influence Financial Analysts Accuracy on Decision Making. PloS one, 11(8), e0160443.

Carpenter, J. N., \& Whitelaw, R. F. (2017). The Development of China's Stock Market and Stakes for the Global Economy↔. Annual Review of Financial Economics, 9(1).

Chandra, A., \& Kumar, R. (2011). Factors influencing Indian individual investor behaviour: Survey evidence.

Charles, M. A., \& Kasilingam, D. R. (2013). Does the investor's age influence their investment behaviour? Paradigm, 17(1-2), 11-24.

Chen, H., \& Volpe, R. P. (1998). An analysis of personal financial literacy among college students. Financial services review, 7(2), 107-128.

Chernev, A. (2003). When more is less and less is more: The role of ideal point availability and assortment in consumer choice. Journal of consumer Research, 30(2), 170-183.

Chia, R. (1994). The concept of decision: A deconstructive analysis. Journal of management studies, 31(6), 781806.

Cohen, A., \& Diamant, A. (2017). The role of justice perceptions in determining counterproductive work behaviors. The International Journal of Human Resource Management, 1-24.

Connolly, T., \& Ordóñez, L. (2003). Judgment and decision making: Wiley Online Library.

Cormier, D., Aerts, W., LEDOUX, M. J., \& Magnan, M. (2010). Web-based disclosure about value creation processes: A monitoring perspective. Abacus, 46(3), 320-347.

Cormier, D., Ledoux, M.-J., \& Magnan, M. (2009). The use of Web sites as a disclosure platform for corporate performance. International Journal of Accounting Information Systems, 10(1), 1-24.

Debreceny, R., Gray, G. L., \& Rahman, A. (2002). The determinants of Internet financial reporting. Journal of accounting and public policy, 21(4-5), 371-394.

DeFond, M. L., Wong, T.-J., \& Li, S. (1999). The impact of improved auditor independence on audit market concentration in China. Journal of accounting and economics, 28(3), 269-305.

Diliberto, R. (2006). Uncovering and Understanding Your Clients' History, Values, and Transitions. Journal of 
Financial Planning, 19(12).

Edwards, W. (1983). Human cognitive capabilities, representativeness, and ground rules for research. Advances in Psychology, 14, 507-513.

Fredberg, T. (2014). If I say it's complex, it bloody well will be: CEO strategies for managing paradox. The Journal of Applied Behavioral Science, 50(2), 171-188.

Gandia, J. L. (2011). Internet disclosure by nonprofit organizations: Empirical evidence of nongovernmental organizations for development in Spain. Nonprofit and voluntary sector quarterly, 40(1), 57-78.

Hair, J. F., Hult, G. T. M., Ringle, C. M., Sarstedt, M., \& Thiele, K. O. (2017). Mirror, mirror on the wall: a comparative evaluation of composite-based structural equation modeling methods. Journal of the Academy of Marketing Science, 45(5), 616-632.

Hartmann, S., Ma, H., \& Vechsamutvaree, P. (2016). Providing Ontology-Based Privacy-Aware Data Access Through Web Services and Service Composition Transactions on Large-Scale Data-and KnowledgeCentered Systems XXX (pp. 109-131): Springer.

Hassan Al-Tamimi, H. A., \& Anood Bin Kalli, A. (2009). Financial literacy and investment decisions of UAE investors. The Journal of Risk Finance, 10(5), 500-516.

Hathaway, I., \& Khatiwada, S. (2008). Do financial education programs work?

Hayes, A. F. (2009). Beyond Baron and Kenny: Statistical mediation analysis in the new millennium. Communication monographs, 76(4), 408-420.

Henseler, J. (2017). Bridging design and behavioral research with variance-based structural equation modeling. Journal of advertising, 46(1), 178-192.

Henseler, J., Ringle, C. M., \& Sarstedt, M. (2015). A new criterion for assessing discriminant validity in variancebased structural equation modeling. Journal of the Academy of Marketing Science, 43(1), 115-135.

Hillenbrand, A., \& Schmelzer, A. (2017). Beyond information: Disclosure, distracted attention, and investor behavior. Journal of Behavioral and Experimental Finance, 16, 14-21.

Howlett, E., Kees, J., \& Kemp, E. (2008). The role of self-regulation, future orientation, and financial knowledge in long-term financial decisions. Journal of Consumer Affairs, 42(2), 223-242.

Hsiao, Y.-J., \& Tsai, W.-C. (2018). Financial literacy and participation in the derivatives markets. Journal of Banking \& Finance, 88, 15-29.

Iyengar, S. S., \& Lepper, M. R. (2000). When choice is demotivating: Can one desire too much of a good thing? Journal of personality and social psychology, 79(6), 995.

Jabbarova, A. I. (2016). Solution for the Investment Decision Making Problem through Interval Probabilities. Procedia Computer Science, 102, 465-468.

Jappelli, T., \& Padula, M. (2013). Investment in financial literacy and saving decisions. Journal of Banking \& Finance, 37(8), 2779-2792.

Jorion, P. (2002). How informative are value-at-risk disclosures? The Accounting Review, 77(4), 911-931.

Kempf, A., \& Ruenzi, S. (2006). Status quo bias and the number of alternatives: An empirical illustration from the mutual fund industry. The journal of behavioral finance, 7(4), 204-213.

Kida, T., Moreno, K. K., \& Smith, J. F. (2010). Investment Decision Making: Do Experienced Decision Makers Fall Prey to the Paradox of Choice? The journal of behavioral finance, 11(1), 21-30.

Lee, R. L., \& Joseph, R. C. (2013). An examination of web disclosure and organizational transparency. Computers in Human Behavior, 29(6), 2218-2224.

Lev, B., \& Zarowin, P. (1999). The boundaries of financial reporting and how to extend them. Journal of Accounting research, 37(2), 353-385.

Lovric, M., Kayman, U., \& Spronk, J. (2008). A conceptual model of investor behavior. ERIM Report Series Reference, No: ERS-2008-030-F\&A.

Lucey, B. M., \& Dowling, M. (2005). The role of feelings in investor decision-making. Journal of economic surveys, 19(2), 211-237.

Lusardi, A., \& Mitchell, O. S. (2007a). Baby boomer retirement security: The roles of planning, financial literacy, 
and housing wealth. Journal of monetary Economics, 54(1), 205-224.

Lusardi, A., \& Mitchell, O. S. (2007b). Financial literacy and retirement planning: New evidence from the Rand American Life Panel.

Lymer, A. (1999). Internet and the future of reporting in Europe. European Accounting Review, 8(2), 289-301.

March, J. G. (1994). Primer on decision making: How decisions happen: Simon and Schuster.

Moore, F. (1994). Taking the sting out of the prisoner's dilemma. The Philosophical Quarterly (1950-), 44(175), 223-233.

Mottola, G. R., \& Utkus, S. P. (2003). Can there be too much choice in a retirement savings plan. Vanguard Center for Retirement Research.

Mouna, A., \& Anis, J. (2017). Financial literacy in Tunisia: Its determinants and its implications on investment behavior. Research in International Business and Finance, 39, 568-577.

Mudholkar, R. S. a. M. N. S. (2007). "It's Time for Metamorphosis: The Transition in the Financial Services Industry in India.". Financial Planning Journal, 9, pp. 18-24.

Phillips, L. D., \& Edwards, W. (1966). Conservatism in a simple probability inference task. Journal of experimental psychology, 72(3), 346.

Pompian, M. M. (2008). Using behavioral investor types to build better relationships with your clients. Journal of Financial Planning, 21(10).

Saxton, G. D., \& Guo, C. (2011). Accountability online: Understanding the web-based accountability practices of nonprofit organizations. Nonprofit and voluntary sector quarterly, 40(2), 270-295.

Saxton, G. D., Kuo, J.-S., \& Ho, Y.-C. (2012). The determinants of voluntary financial disclosure by nonprofit organizations. Nonprofit and voluntary sector quarterly, 41(6), 1051-1071.

Schwartz, B. (2004a). A Nation of Second Guesses. New York Times, 22.

Schwartz, B. (2004b). The paradox of choice: Why less is more. New York: Ecco.

Schwartz, B. (2005). Freedom, Choice, Wealth and Welfare. Finance \& Bien Commun(2), 47-53.

Sethi-Iyengar, S., Huberman, G., \& Jiang, W. (2004). How much choice is too much? Contributions to 401 (k) retirement plans. Pension design and structure: New lessons from behavioral finance, 83, 84-87.

Simon, H. A. (1965). Administrative behavior: a study of decision-making process in administrative organisation: Free Press.

Sjöberg, L., \& Engelberg, E. (2006). Attitudes to economic risk taking, sensation seeking and values of economists specializing in finance. Centre for Risk Research, working paper 2006, 3.

Slovic, P., Finucane, M., Peters, E., \& MacGregor, D. G. (2002). Rational actors or rational fools: Implications of the affect heuristic for behavioral economics. The Journal of Socio-Economics, 31(4), 329-342.

Smith, J. F., \& Kida, T. (1991). Heuristics and biases: Expertise and task realism in auditing. Psychological bulletin, 109(3), 472.

Smith, W. K., \& Lewis, M. W. (2011). Toward a theory of paradox: A dynamic equilibrium model of organizing. Academy of management Review, 36(2), 381-403.

Valentinetti, D., Rea, M. A., \& Basile, C. (2016). Differences between national reporting practices and IFRS for SMEs presentation and disclosure requirements: Evidence from Italy. International Journal of Accounting and Financial Reporting, 6(2), 146-174.

Wong, A. W.-K., Chiu, H.-C., Wang, J., Cao, J., Wong, S.-S., \& Chen, H.-C. (2017). An early locus of associative and categorical context effects in speech production: evidence from an ERP study using the picture-word interference paradigm. Language, Cognition and Neuroscience, 32(10), 1305-1319.

Yu, P.-L., \& Chen, Y.-C. (2010). Blinds, fuzziness and habitual domain tools in decision making with changeable spaces. Human Systems Management, 29(4), 231-242. 